\title{
Sosyal Yenileşim
}

\section{Ve Tasarimın}

\section{Değişen Rolleri}

\section{Serkan Bayraktaroğlu \\ Kadir Has Üniversitesi}

Sanat ve Tasarım Fakültesi, Endüstri Ürünleri Tasarımı

Seçil Şatır

İstanbul Teknik Üniversitesi

Ahu Akgün

İstanbul Teknik Üniversitesi

\section{Giriş}

Modern çevreci hareketin başlangıcı sayılan Rachel Carson'ın 'Sessiz Bahar' adlı kitabının ardından 52 yıl, Birleşmiş Milletler'in sürdürülebilir kalkınmayı tanımladığı ‘Ortak Geleceğimiz' raporun ardından ise 27 yıl geçti. Tüketicilerin sürdürülebilirlik algısı ve konu ile ilgili çalışmalar çoğalsa da, insanoğlunun yayılma içgüdüsü ve ekosistemin bu büyümeyi karşılayabilecek kapasitesi arasındaki dengesizlik, ekosistem aleyhinde hala devam etmektedir. Çevre ile ilgili büyüyen bu endişenin yanında, kalkınmadaki dengesizlikler ve küreselleşmenin tetiklediği sosyal sorunların daha da karmaşık hale gelmesi, diğer tüm alanlarda olduğu gibi tasarımda da karşılık bulmaktadır.

Çalışmanın amacı sürdürülebilir kalkınma, sosyal yenileşim ve tasarım arasındaki ilişkiyi kurmak ve bu ilişki ağında tasarımcıların üstlenebileceği yeni rolleri keşfetmektir. Çalışmada öncelikli olarak endüstri ürünleri tasarımının rollerine odaklanılsa da, literatürde de olduğu gibi, sosyal fayda yaratma amacı güden projelerde sıkça roller arasındaki geçişkenliğin yaşanıyor, odağın somut ürün tasarımını aşıyor olmasından dolayı, çalıșmada daha kapsayıcı anlamda bir tasarım pratiği tartışılmaktadır.

\section{Sürdürülebilir kalkınma}

Gelecek nesillerin ihtiyaçlarını karşılayabilme imkanlarını gözeterek bugünün ihtiyaçlarını karşılayabilmenin altını çizen sürdürülebilir kalkınma kavramı (Brundtland, 1987), uygulamada çevre ve sosyoekonomik gelişmeler arasındaki ilişkilerin çok iyi kurgulanmasını zorunlu kılmaktadır. Büyümenin sınırları, kalkınmadaki dengesizliklerin giderilmesi ve ekonomik stratejilerin bu bakış açısıyla belirlenmesi yönünde ortak tavır almayı hedefleyen Birleşmiş Milletler (BM), 2012 yılı Haziran ayında RIO+20 Sürdürülebilir
Öz

Son yıllarda giderek daha fazla araştırmaya konu olan sosyal yenileșim için tasarım, özellikle kalkınmakta olan ülkelerde ümit vaat edici, dönüştürücü bir dinamizmin tetikleyicisi olabilecek bir potansiyele sahiptir. Karmaşık sosyal meseleler karşısında, etkin ve bütüncül çözümler üretebilmek için, tasarımın sivil toplum örgütleri, kalkınma ajansları gibi farklı paydaşlarla birlikte çalışması, kendi alanındaki deneyimini yeni bilgi ve beceriler ile harmanlaması gerekmektir.

Çalıșmanın amacı; bu türden ortaklıkların gerçekleştiği, sosyal fayda sağlayan, sonuçlarının okunabileceği kadar olgunlaşmıs projeler üzerinden sürdürülebilir kalkınma, sosyal yenileşim ve tasarım arasındaki ilişkiyi kurmak ve bu ilişki ağında tasarımcıların üstlenebileceği yeni rolleri keşfetmektir.

$\mathrm{Bu}$ amaç doğrultusunda, makale Hindistan özelinde var olan sosyal yenileşim içerikli projeleri inceleyerek süreçte yer alan paydaşları irdelemektedir. Çalışmanın sonuçları göstermektedir ki tasarımcılar beş farklı ama geçişken kimlik ile ve bu kimliklerinin onlara tanımladığ $\breve{s}_{1}$ sınırlar dahilinde ekonomik ve sosyal değerin birlikte doğduğu sosyal yenileşimlerin gerçekleşmesini desteklemektedirler.

Abstract

Design for social innovation, as an emerging research field, has a potential to trigger a promising and transforming dynamism for developing countries. In order to create effective and holistic solutions for complicated social problems, design should collaborate with various stakeholders such as $N G O$ 's and development agencies, and blend in new skills and knowledge with its own domain.

To be able to draw connections between sustainable development, social innovation and design, and to explore emergent roles of design, the purpose of the research is examining this type of collaborative projects. which are mature enough to observe their outcomes and have generated social value. With this purpose, the article studies the stakeholders while examining several projects dealing with social innovation in the context of India. Results of the study indicate that designers, with five distinct but transitive identities, take different roles to realise social innovations which economic and social value are procreated together.

Anahtar Kelimeler:

Tasarım, Sosyal Yenilessim, Sürdürülebilir Kalkınma, Sürdürülebilirlik, Hindistan.

\section{Keywords:}

Social Innovation, Sustainable Development, Sustainability, India. 
Kalkınma Konferansı'nı düzenlemiştir. Türkiye dahil 188 ülkenin katıldığ önemli toplantı sonrası ortak sürdürülebilir kalkınma hedefleri belirlenmesi hususunda katılımcı ülkeler uzlaşmış, devletler arası daha şeffaf ilişkiler kurulmasının önemi vurgulanmıştır. Fakat somut adımlar atılması konusunda bağlayıcı bir karar alınamamıştır. Dünya çapında yoksullukla savaşan en büyük teşkilatlardan biri olan Cooperative for Assistance and Relief Everywhere (CARE) toplantıyı politik bir komedi olarak nitelendirmektedir (Romero ve Broder 2012).

Bir yandan atılacak adımlar ile ilgili eylem planları uluslararası düzeyde tartış1lırken, diğer taraftan temel kavramlar konusunda kafa karışıklığı hala devam etmektedir. Kalkınma Bakanlığı

Sürdürülebilir Kalkınma Portalı'nda 'Yeşil Büyüme' kavramını çevresel iyileştirmelere katkı sağlayan mal ve hizmetlerin yatırım ve tüketimini önceliklendiren bir anlayış olarak tanımlamış ve şunu da eklemiştir;

"Ancak, genel anlamda yeşil ekonomi kavramının neyi kapsadı ̆̆ net olarak belirlenmediği gibi üzerinde uzlaşılmış bir tanım da bulunmamaktadır. Bu nedenle, ülkeler özgün koşullarl çerçevesinde kendilerine özel tanımları ortaya koymaktadır" (TC Kalkınma Bakanlı̆̆ 2014 ).

Yeşil ekonomi tanımında yer alan, karar verirken çevresel iyileşmenin tetikleyicisi olacağı umulan üretim-tüketim seçeneğini tercih etmek üç nedenden ötürü yeterli ve gerçekçi bir çaba olmayabilir:

- 'Çevresel iyileştirme’ kavramını tanımlayabilmek için eylemlerin sebep olduğu karbon emisyonundan başka ortak kabul gören ve ölçülebilir değerler henüz uygulamada yer edinememiştir.

-Bu tanımda meselenin sosyal boyutu görmezden gelinmiştir.
-Tüm bu tercih etme halinin, lobi yapma gücü daha fazla olan sermayenin yönlendirmesiyle çoğu zaman iktisadi beklentilerin lehine geçekleşme ihtimalinin yüksek olmasıdır.

Yeşil ekonominin ötesinde sürdürülebilir kalkınmanın iyi anlaşılabilmesi için kalkınma kavramını belki de yeniden tartışmak gerekebilecektir. Türkçede kalkınma, İngilizcedekine benzer şekilde;

"Bir ekonomide halkın değer yarglları, dünya görüşü ile tüketim ve davranış kalıplarındaki değişmeleri içerecek biçimde toplumsal ve kurumsal yapıda dönüşüme yol açan büyüme" olarak yani ekonomik büyüme ve tüketim davranışları üzerinden tanımlanmıştır (TDK Bilim ve Sanat Terimleri Ana Sözlüğü, 2014).

Tanımda ekosistemin kapasitesi düşünülmediğinden, bu haliyle bir terim olarak 'kalkınma' bir yandan sürdürülebilirlik kavramı ile çelişebilirken (Redclift 2005), diğer yandan kendi başına da bulanık bir algı yaratmaktadır. Kalkınma, sadece üretim ve tüketim seviyesindeki artış olarak değil de herkes için ekonomik sosyal ve kültürel bağlamda daha iyi bir hayat olarak algılandığında, aslında bir tür insani hakkı temsil edecektir. Dolayısıyla kalkınma bağlamında sürdürülebilirlik sadece çevre, sosyal adalet, ekonomik büyüme içeren bir kavram değil bunun ötesinde insanlarla, insanların bireysel ve kültürel olarak hayatlarını devam ettirebilmeleriyle de ilgilidir.

Birleşmiş Milletler Kalkınma Programı (UNDP) 2000 yılında yayınladığı bir deklarasyonla 'Milenyum Kalkınma Hedefleri' olarak tanımladı ğ 1 ve 2015 yılına kadar ulaşılması amaçlanan sekiz başlık belirlemiştir. Türkiye ise bu sekiz başlıktan özellikle üç temel alana odaklanmış durumdadır (T.C. Başbakanlık Devlet 
Planlama Teşkilatı Müsteşarlı̆̆ı 2010, 61-68)

-Demokratik yönetişimin sağlanması için kapasite geliştirme,

-Yoksulluğun azaltılması için çaba gösterilmesi,

-Çevre ve sürdürülebilir kalkınma.

Yoksullukla mücadele bağlamındaki hedeflere ulaşmakta, gelişmekte olan diğer bir çok ülke gibi ülkemizde de kırsalın durumu önem kazanmaktadır. Kırsal kalkınma yaklaşımları başta modernleşme ile teknoloji transferi ve adaptasyon üzerinden ilerlerken 1950'lerden itibaren sürekli evrilmiş, 2000'lerden itibaren bir yandan sosyal problemleri çözerken diğer yandan ekonomik girdi sağlayacak, 'sürdürülebilir geçim kaynakları yaklaşımı' gibi yerelde kendine yetebilen dağıtılmış sosyo-ekonomik sistemler üzerine odaklanılmıştır (Ellis ve Biggs, 2001, 439). Tabandan doğacak bu tür çözümlerin tutunabilmesi ve gelişebilmesi için giderek daha fazla tartışılan yaklaşımlardan biri de sosyal yenileşimdir.

\section{Sosyal yenileşim}

Her ne kadar literatürde sosyal yenileşim göreceli olarak yeni bir kavram olsa da sosyal yenileşimin kendisi uygulamada aslında tarih boyunca örneklerini gördüğümüz türden iyileştirmelere karşılık gelmektedir. Günümüzde uzaktan öğrenme, ya da mikro kredi gibi pratiklerle somutlaşan sosyal yenileşim, geçmişte de kooperatifler ya da anaokulları olarak var olmaktaydi.

Phills vd. (2008, 36) Stanford Social Innovation Review'in 2003 y1lında yayınlanan ilk editör yazısında 'sosyal ihtiyaçlar ve problemleri çözmek için uygulamaya sokulacak yeni yöntemlerin geliştirilmesi ve desteklenmesi süreci' olarak tanımlanan sosyal yenileşimi 2008'deki makalelerinde şöyle revize etmiştir;

“...bir sosyal problemin giderilmesi için yepyeni bir çözüm yolu, ya da mevcutlarından daha verimli, daha etkin, daha sürdürülebilir olan, öncelikli olarak bireyden ziyade toplumun tümünü hedef alan bir alternatif..."

Murray, Caulier-Grice ve Mulgan (2010, 3) sosyal yenileşim; hem karşılanmamış sosyal ihtiyaçları gideren hem de yeni sosyal ilişkiler ve işbirlikleri kurulmasına ön ayak olan, ürün, hizmet ya da sistem olarak karşımıza çıkan yeni fikirler olarak tanımlamaktadır. Phills vd. $(2008,39)$ ise tüm bunlara sosyal hareketleri de eklemekte, Jegou ve Manzini (2008) ise özellikle teknolojik yeniliklerdense, davranış değişikliklerinin önemine vurgu yapmakta ve tepeden inme değil aşağıdan yukarıya kuluçkalanan çözümlerin daha etkin olacağını belirtmektedirler. Böylece yerelde işbirliği ile gerçekleşen yaratıcı girişimler, sistemde önemli değişiklikler yapabilecektir.

Literatürde sıkça sosyal yenileşim ile ilişkilendirilen bir diğer kavram bu türden yerel oluşumları da kapsayan sosyal girişimciliktir. Güler (2011) yoksullukla mücadele için dinamizm sağlayan katalizörlere benzettiği sosyal girişimleri, sosyal girişimcilerin kurduğu örgütler olarak tanımlamaktadır.

Tanımlardan da anlaşılacağı gibi, ne sosyal yenileşim ne de sosyal girişimcilik net sinırları tarif edilebilen alanlar değiller. Hemen hemen tüm özel ya da kamu işletmeleri, ya da kar amacı gütmeyen işletmelerde sosyal yenileşim tanımına girecek yaratıcı eylemler gerçekleşiyor olabilir. Aynı zamanda bir örgüte benzetilen sosyal girişimler, bilindik iş modellerinin ötesinde, sektörler arası rol 
geçişlerine de sahne olmaktadır. Kamu sektörü, özel sektör, kar amacı gütmeyen organizasyonlar ve sivil toplum örgütleri sosyal yenileşim projelerinde birlikte çalışabilmekte, birbirlerinin yöntemlerini kullanabilmektedirler.

Organizasyonel sınırların bulanıklaşmasına verilebilecek en önemli örnek, şüphesiz ki Muhammed Yunnus'un Gramen Bank ile gerçekleştirdiği mikro kredi uygulamasıdır (Phills vd., 2008). Bu örnekte, sosyal yenileşim bir banka ya da krediden istifade eden yerel işletmeler değil, küçük girişimleriyle insanlara gelir elde etme imkanını veren mikro-kredi yöntemidir.

Bu noktada, sosyal yenileşimi herhangi bir yenilikten ayıran en önemli unsur sosyal değer üretmesidir (Auerswald, 2009). Diğ er taraftan bir çeşit sosyal faydanın tüm ticari faaliyetlerde ortaya çıkabileceği düşünülebilir. Kar elde etme amacıyla üretilip satılan tüm ürünlerin ve hizmetlerin insan hayatını kolaylaştırmaya yönelik geliştirildiğini varsayarsak, ticari faaliyetlerin sonuçları muhakkak sosyal bir fayda sağlayacaktır. Oysa sosyal yenileşimin vurguladı̆̆ı sosyal değer, sürecin bir yan ürünü olarak, amaçtan bağımsız ortaya çıkan değil, ana hedeflerinden biri olmalıdır (Phills vd. 2008; Sinkovics vd. 2014, 696).

\section{Sosyal yenileşim için tasarım}

Sosyal etki için tasarım, sosyal fayda için tasarım ya da sosyal yenileşim için tasarım kavramları, tasarımın dünya üzerinde bıraktığ $\breve{l}_{1}$ etkiyi kritik etme adımları ile doğmuştur denilebilir. Form ve malzemeye odaklanarak ürünleri daha geniş kitlelere ulaştırmak, insan odaklı çözümler geliştirmek endüstri ürünleri tasarımının sosyal kaygılarının belki de ilk tezahürleridir.

1960'ların sonunda ve 1970'lerin başında, Avrupa ve Amerika'da sosyal açıdan faydalı tasarımlar konuşulmaya başlanmıştır. 1976 Nisan ayında, Londra'da bulunan Royal Collage of Art'da, Victor Papanek ve Gui Bonsiepe gibi katılımcıların görüşlerini sunduğu "İhtiyaç için Tasarım: Tasarımin Sosyal Katkıs”" sempozyumu, düzenlenmiştir.

Her ne kadar tasarımın sürdürülebilirlik ile olan yakın ilişkisi, çok daha uzun süreden beri, tasarlanmış ürünlerin çevreye olan etkileri çerçevesinde araştırılsa da, özellikle 2000'lerin başından itibaren, sosyal fayda konusunda çalışan organizasyonların sayısı arttıkça, tasarımın sosyal etkisi de popüler bir araştırma ve uygulama alanı haline gelmiştir.

Emilson vd. (2011, 23-29) makalelerinde sosyal yenileşim için tasarım yaklaşımlarını öncül uygulamalar üzerinden şöyle sıralamaktadır;

\section{-Hizmet tasarımı, dönüşüm tasarımı ve} kamu hizmetleri için tasarım:

İngiltere'de doğmuştur. İngiliz Tasarım Konseyi'nin devlet ve kamu sektörü ile birlikte gerçekleştirdiği çalışmalar, hizmet tasarımı endüstrisinin hem kamu hem özel sektörde yer edinmesini sağlamıştır. DOTT Cornwall, ThinkPublic, Engine gibi oluşumlar buna örnek verilebilir.

\section{-Sürdürülebilir yaşam tarzları için yaratıcı topluluklar ve sürdürülebilir tasarım araştırmalart:}

Manzini'nin de içinde bulunduğu bir grup araștırmacı Politecnico di Milano'da tabandan doğan toplumsal yeniliklerin geliştirilmesinde tasarımın rolüne odaklanmıştır. DESIS (Sosyal Yenileşim ve Sürdürülebilirlik için Tasarım) ağ $\mathrm{bu}$ 
yaklaşımın bir sonucu olarak doğmuştur.

\section{-Tasarım düşüncesi ve kalkınma için tasartm:}

ABD'de yerleşmiş bazı tasarım danışmanlık şirketleri tarafından uygulanmaktadır. Özellikle kalkınmakta olan ülkelerde projeler gerçekleştiren bu gruplar arasında IDEO, Project H Design (eğitim) ve Mayo Clinic (sağllk) gösterilebilir.

İngiltere'de doğan ve Avrupa'da olduğu gibi ABD'de de karşılı̆̆ını bulan, temelde hizmet tasarımı pratiğiyle ilerleyen sosyal yenileşim yaklaşımları aslında gelişmiş ülkelerde yaşlanan nüfusun ihtiyaçlarını karşılamakta zorlanan devletin, hizmetlerini iyileştirmesinde katalizör işlevini görmektedir. Örneğin İngiliz Tasarım Konseyi'nin önderliğinde 2009 yılında başlayan Dott Cornwall programı 50 yaş ve üzeri İngiliz vatandaşlarının ihtiyaçları konusunda projeler geliştirmektedir.

DESIS ise sürdürülebilir yaşam tarzları, sosyal yenileşim, yaşam kalitesi, sürdürülebilirlik için tasarım gibi konularda araştırma yapan merkezlerin oluşturduğu, BM Çevre Programı (UNEP) tarafından da tanınan bir ağı temsil etmektedir. DOTT'a benzer şekilde enerji, sağlık, eğitim ve özellikle de gıda ile ilgili meselelerle ilgilense de, projelerinde tabandaki dayanışma ile doğacak ve yayılacak hareketleri öngörmesi açısından özgünleşmektedir. Bir diğer farklılık ise DESIS' in sadece Italya gibi kalkınmış ülkelerde değil, Güney Afrika, Hindistan, Brezilya ve Türkiye gibi kalkınmakta olan ülkelerdeki üniversitelerde kurulu araştırma merkezlerini de kapsayan uluslararası bir ağ olmasıdır. Bu sebeple DESIS tasarım eğitiminin dönüşümünde de önemli yaklaşımlar geliştirmekte ve bunu açık kaynak olarak tüm dünyadaki eğitim kurumları ile paylaşmaktadır.

DESIS'in yaklaşımını en iyi özetleyecek olan Manzini'nin $(2012,27)$ ortaya attığ1 SLOC yani Küçük, Yerel, Açık ve Bağlı yaklaşımı olacaktır. Manzini'nin anlatmaya çalıştığ ' 'küçük', 1973'de 'Küçük Güzeldir' kitabının yazarı, ekonomist Schumacher'in tarif ettiği 'küçük' kavramindan biraz daha farklı olarak, sadece kendine yeten değil, büyük bir şebekeye bağlı olan bir düğüm olarak hayat bulmaktadır. SLOC'un tanımına göre bu küçük düğümler büyük sistemde birbirlerine bağlıdır ve açık bir iletişimdeğişim halinde yerelliğini kaybetmeden yaşamaya devam edebileceklerdir. $\mathrm{Bu}$ yaklaşımda daha esnek, güçlü, kolayca adapte olan ve dağıtılmış üretim sistemleri öngörülmektedir. Manzini (2012, 27) teknolojik ve sosyal yenileşimin birlikteliği ile sistemsel değişimlerin tetiklenebileceğinin altını çizmekte ve bu değişimlerde de tasarım yönlü aktörlere önemli görevler düştüğünü vurgulamaktadir.

IDEO'nun da aralarında bulunduğu üçüncü grup ise tasarım düşüncesini kullanarak, öncelikli olarak gelişmekte olan ülkeler ile piramidin tabanı olarak nitelendirilen üçüncü dünya ülkelerindeki temel sıkıntıları çözmek amacıyla projeler geliştirmektedir. Bu temel sıkıntılar arasında temiz su ve gıdaya ulaşım, iletişim, elektrik ve temel eğitim sayılabilir.

Sosyal yenileşim için tasarım, doğası gereği çözüm sunmayı hedeflediği meselelerin yaşandığı coğrafyaya özgün sosyoekonomik koşulları değerlendirmektedir. Sinkovics vd. (2014) gelişmiş ülkelerde sosyal değer üretme ve ticaretin iki ayrı faaliyet olarak var olmasının 
anlaşılabilir olduğunu ama özellikle gelişmekte olan ülkeler ve az gelişmiş ülkelerde önemli bir sosyal değer ya da fayda üretmeyen ticari bir faaliyetin kendi başına sürdürülmesinin mümkün olamayacağını vurgulamaktadır. Dolayısıyla gelişmiş ülkelerdeki sosyal değer üretme faaliyeti gelişmekte olan ülkelerden farklı olacaktır. Bu bakış açısıyla, sıralanan öncül uygulamaların iki halde tezahür ettiği söylenebilir.

Gelişmiş batılı ülkelerde, devletin sunması gereken hizmetlerin iyileştirilmesi ya da Meroni'nin (2010) bahsettiği gibi Milano şehrinin gıda ihtiyacını kendi kendine karşılaması gibi projeler gerçekleşirken, piramidin tabanındaki üçüncü dünya ülkelerinde temel ihtiyaçlar ve altyapılar ile ilgili projeler uygulanmaktadır.

Uygulamalardan anlaşılabileceği gibi, sosyal yenileşim için tasarım, sosyal faydanın üretilmesini ve yayılmasını teşvik etmekte hem mevcut girişimleri desteklemek hem de yenilerinin hayat bulmasını sağlamak için tasarım düşüncesini ve bilgisini kullanmak olarak tanımlanabilir. $\mathrm{Bu}$ yeni bağlamda, tasarımın ilgi alanı genişlemekte, tasarımcıların rolleri ve kimlikleri değişmektedir.

\section{Tasarımın değişen rolleri}

Tasarım doğuşundan itibaren evrilmeye devam ederken, yeni yeni roller de üstlenmiştir. Valtonen'in (2005) endüstriyel tasarımın değişen rolleri üzerine Finlandiya bakışını kaleme aldığı makale ve Tan'ın (2012) hizmet tasarımı alanında yaptığı araştırmayı sunduğu doktora tezi bunlar arasında sıyrılan önemli kaynaklardandir.

1950’lerde çoğunlukla ürünlerin yaratılmasında kilit rol oynayan endüstriyel tasarımcılar daha sonraları çoklu disiplinli takımlar içinde karmaşık teknolojik çözümlemelerin altından kalkmak üzere roller üstlenmiş, son kullanıcı konusunda uzman haline gelmiştir. Tasarımcılar, tasarım yönetimi alanında roller edinmiş, markalar ve deneyimler yaratmak üzere görevler yerine getirmiş ve son olarak da yenileşimi ulusal seviyede destekleyen ve sürükleyen liderler olmaya başlamıştır (Valtonen, 2005). Valtonen'in bu tespiti, başta gelişmiş ülkeler olmak üzere kalkınmakta olan ülkelerde de benzer izde ilerlemektedir.

Tan (2012) daha genel manada tasarımcıların üstlendikleri rolleri literatürden özetleyerek şöyle sıralamaktadır; stratejist, birlikte-yaratan, hikaye anlatıcı, rasyonalist, şöhret, işbirlikçi, hızlandıran, birleştirici, müzakereci, kolaylaştırıcı, görselleştiren, kılavuz, arabulucu, koordinatör. Tan (2012) kendi araştırmasında ise bunlara ek olarak kışkırtıcı (provokatör) ve sosyal girişimci rollerini tespit etmiştir. Kışkırtıcı, yazarın tarifinde eylemci (aktivist) rolünün çok da uzağına düşmemektedir. Diğer yandan, sosyal girişimcilik rolü, sosyal yenileşimin ve sosyal girişimin muğlak doğası sebebiyle aslında sayılan tüm bu rolleri de içerecek şekilde konumlandırılabilir.

Tanımlar ve etiketler koymanın ötesinde, bazı yazarlar tasarımdaki değişimi, ilgilenilen bu yeni alanlarda tasarımın yapabilecekleri üzerinden tartışmaktadır.

Bunlardan biri olan Manzini (2012, 28-29) tasarım disiplininin bu yeni ve muğlak alanlarda karşılaşacağı üç önemli değişimden bahsetmektedir:

-Tasarlanacak 'objeler', çağdaş toplumlar için artık karmaşık, maddi ve maddi olmayan sistemler halindedir ki bu; ürünSayı 18, $2014 \mid 41$ 
ler, hizmetler, insanlar ve mekanlar birbirlerine daha önceden var olmayan şekillerde bağlanmaktadır.

-Bu halde tasarımcılar sürdürülebilir çözümlerin algılanması, geliştirilmesi ve yönetilmesi için esnek şebekeler, tasarlama ağları oluşturacaklardır.

-Dağıtılmış üretim sistemlerinde, geleneksel olarak tanımlanan maddi ürün kavramının tekrar düşünülmesi gerekecektir. Zira yeniden konumlandırılan bu yerel üretim ağlarında üretim ve dağıtım sistemleri bugünün imalat modellerine uymayacaktır.

Morelli (2007), bu öngörüleri temellendirecek şekilde tasarımcıların da içinde bulunduğu 'sosyal aktörlerin' globalleşmenin etkisiyle karşılaştı̆̆ımız ekonomik, kültürel ve sosyal sonuçların üzerinde çalışmak zorunda kalışlarına dikkat çekmektedir. Fakat bu yeni sosyal bağlılık hali, daha evvel karşılaştığımız endüstriyel toplumun reaksiyonlarından çok daha farklı olarak ürün, üretim ve teknolojiden daha fazla sistemler, hizmetler, organizasyonlar ve politikalara odaklı gerçekleşmektedir.

$\mathrm{Bu}$ değişen şartlarda, tasarımcı profilinin, somut olarak ürün tasarımında gerekli bilgi ve beceriye sahip, görselleştirme ve bütüncül düşünme yetenekleri gelişmiş ama aynı zamanda farklı disiplinlerle birlikte çalışabilecek, onları anlayabilecek, stratejiler oluşturabilecek ve hatta onları yönetebilecek yetkinlikte olması gerekecektir. Bu tanım, McKinsey gibi danışmanlık şirketlerinin uzun zaman önce fark ettikleri bir çalışan profilini tarif etmektedir, 'T tipi insanlar' (Brown 2009; Yavuz 2014).

42 Sayı 18, 2014
İyi birer yönetici adayı olacağı tahmin edilen insanların kabiliyetlerinin $\mathrm{T}$ harfine benzetilmesi tamamen harfin formuna yapılan bir göndermedir. Bu tip insanlar için T harfini oluşturan dikey uzun çubuk, bu insanların, muhtemelen eğitimini aldıkları, asıl becerilerini temsil etmektedir. Bir işletmeci için bu analitik düşünme yeteneği ve problem çözme becerisi olabilir. T harfinin iki yana uzanmış kolları ise bu kişilerin diğer disiplinlere olan empatisini, yakınlığını temsil etmektedir. $\mathrm{Bu}$ tip insanlar göreli olarak daha hızlı öğrendiği, adapte olabildiği için iyi birer yönetici adayı olmaktadırlar. McCulagh (2010, 1) Core77'de yayınlanan yazısında, IDEO'nun bu benzetmeyi kullanarak T tipi tasarımcıyı nasıl tarif ettiğinin altını çizmiştir. IDEO için T'nin uzun dikey çubuğu tasarım alanındaki uzmanlığa tekabül etmektedir ki bu yaratıcılık, çizim teknikleri, görselleştirme ve model yapmak gibi tasarım eğitiminin olmazsa olmaz bilgi ve becerilerini içerecektir. T'nin iki yana uzanan kolları ise davranış bilimlerinden, etnografiye kadar uzanabilen tasarımcının empati kurduğu ve becerilerini geliştirdiği diğer disiplinleri temsil etmektedir.

IDEO tasarım düşüncesi kavramı etrafında şekillendirdiği yaklaşımında, bu T tipi insanların daha rahat kullanabileceği, çoklu disiplinli bakış açıları içeren, sosyal etki için tasarım, insan odaklı tasarım gibi araçlar geliştirmekte ve bunları kamuya açık olarak yayınlamaktadır. IDEO’nun sunduğu bu özgür araç seti ile dünyanın herhangi bir yerinde sosyal bir sorun için çözüm geliştirmek isteyen bir tasarımcı, adım adım neler yapabileceğini tayin edebilecek ve sonuca ulaşacaktır. Oldukça basitleştirilmiş bu yaklaşım bir yandan sürecin hızlı bir şekilde gerçekleşmesi için etkin bir araç olarak sosyal yenileşimin 
tetiklenmesine ön ayak olurken, diğer taraftan yine bu basitliği yüzünden farklı coğrafyalardaki sosyokültürel iklimlere ayak uydurabilmekte sorun yaşayabilecektir. Sosyal yenileşim için tasarım yaklaşımını, basitleştirilmiş bir metot olarak sunmak hem sosyal yenileşimin muğlak karakteri sebebiyle hem de bunu gerçekleştirecek kişilerin ve kurumların çeşitliliği yüzünden oldukça güçtür. McCulagh'ın (2010) T şekilli tasarımcılar ile ilgili eleştirisi de tam bu yüzden yerini bulmaktadır. Bu türden projeleri gerçekleştirecek tasarımcıların sahip olması gereken tasarım dışı becerileri henüz net olarak tanımlanmamıştır.

Gelişmekte olan bir alan olduğundan, tasarımın yapabileceklerini, üstlenebileceği yeni rolleri ve bu süreçte ihtiyaç duyacağı yeni bilgi ve becerileri daha evvel gerçekleştirilmiş projeler üzerinden okumak yerinde olabilir. Kabaca gruplandırdığımızda, ana akımlardan olan IDEO'nun yaklaşımı özellikle üçüncü dünya ülkelerindeki sosyal tasarım projelerinde uygulama alanı bulurken, DESIS ve DOTT gibi Avrupa'da doğmuş perspektifler, hizmet tasarımına yaptıkları vurgu ve çoğu zaman çözüm için gerektirdikleri altyapı sebebiyle ancak gelişmiş ülkeler ve gelişmekte olan ülkelerin göreli olarak kalkınmış şehirlerinde daha kolay uygulanabilecek haldedir. Oysa Türkiye, Brezilya, Hindistan gibi kalkınmakta olan ülkelerin büyüyen ekonomilerinin getirdiği dinamizmin kırsalda yarattığı etkiyi göz önünde bulunduracak, Bin Yıl Kalkınma Planları'ndaki hedeflere ulaşmamızı kolaylaştıracak, aynı zamanda bu alanlardaki sosyal sıkıntıları çözebilecek yaklaşımlara ihtiyaç vardır. Bu bağlamda, Türkiye gibi gelişmekte olan ülkelerin faydalanabileceği, özelleşmiş sosyal yenileşim yaklaşımları ve bu yaklaşımlarda tasarımın üstlenebileceği olası rollerin tespiti gerekmektedir. İnal ve Biçkes (2006), devletin üstün olduğu bir yapıdan, devletin hatta kar amaçsız sektörün merkezde olduğu bir yapıya doğru gerçekleşen değişimin en önemli nedenlerinden birinin de devletin, halkın tüm sosyal ihtiyaçlarını etkinlik ve verimlilik açısından yeterince karşılayamaması olarak belirtmiştir. Refah devletindeki bu dönüşüm, farklı sektörlerden aktörleri bir araya getirmekte, rolleri ve yöntemleri arasındaki geçişleri tetiklemektedir. Bu dönüşüm daha evvel sosyal fayda odaklı olan organizasyonların pazar yönlü hale gelmesini teşvik edecektir. İnal ve Biçkes'in (2006, 12-14) de vurguladığ1 gibi bu ancak müşterilerin ve pazarın anlaşılabilmesi için bütüncül bir bilginin elde edilmesi ile gerçekleşecektir. $\mathrm{Bu}$ yeni, dinamik, geçişken ama bir o kadar da muğlak alanda ihtiyaç duyulan kaynaştırıcı rolü tasarımcı üstlenebilir.

\section{Özelikle tasarımcıdan beklenen T tipi} paydaş profilinde, sosyal yenileşim ve kalkınma bağlamında T'nin kollarının hangi bilgi ve becerilere doğru uzanacağını tartışmak, İnal ve Biçkes'in (2006, 12-14) işaret ettiği alanda etkin bir rol edinmek için zaruri gözükmektedir.

Amir'in (2004) üçüncü dünya ülkelerinde tasarım politikalarının endüstriyel üretimin ihtiyaçlarını karşılayabilmeye odaklanarak, yerel halkın fakirliği alt edebilme, temel ihtiyaçları giderebilme gibi beklentilerini göz ardı etmesi eleştirisi, çok yerindedir. Tüm bu dönüşüm için, gelişmekte olan ülkeler tasarımı sosyal gerçekliğe daha fazla yaklaştırmak zorundadır. Küçük, yerel, merkezi olmayan, temiz teknolojiler kullanan girişimler, yerel halkın ihtiyaçlarını çevreyi kirletmeden sağlayabilir, onlar için 
sürdürülebilir geçim kaynakları sağlayabilir. Böyle girişimlerin gerçekleşmesinde rol alacak olan tasarım, yönetim ve organizasyonu da kendi oyun alanına sokabilecektir (Buchanan 2008); ve tasarımın bütüncül yaklaşımı organizasyonların yönetilmesinde, iş modeli geliştirmekte de zenginleştirici bir araç olabilir. Jonas vd. (2009) tasarımcılar için yeni sosyal müdahale alanı tanımlamadığı sistemde, işletmelerin değişen sosyal rolünü ise şöyle ifade etmektedir:

"Bu tür organizasyonlar, ürün sağlamaktan ziyade yerel ağları, paydaşları desteklemekte, çözüm yerine, ürün ve hizmet sistemlerini içeren yarı tamamlanmıș platformlar ile insanların kendi ihtiyaçlarına göre kendi de ğerlerini yaratmalarını să̆lıyorlar".

Bu bağlamda tasarımcıların yeni rolleri, senaryolar, platformlar ve yönetim stratejileri geliştirerek küçük girişimleri, yerel enstitüleri, kooperatif gruplarını ve bireyselliği mümkün kılarak bitmiş ürün yerine onların kendi sonuçlarını yaratmalarını sağlamak olacaktır (Jonas vd. 2009). Benzer durum, Türkiye için de akademisyenler tarafından tartışılmaktadır. Türk tasarımcılar için tasarımı yeni bir perspektifle algılamanın karşısında, modernizasyon ve ülkenin geçirdiği endüstriyelleşme sürecine bağlı sebeplerden dolayı zihinsel bir engel olduğunun altı çizilmektedir ( $E r$ ve Kaya 2008). Bu zihinsel engeli aşmanın bir yolu da hayat bulmuş örnekler üzerinden tasarımın rolünü ve tasarım eğitimini yeniden tartışmak olabilir.

\section{Hindistan deneyimi}

Çin, Hindistan, Brezilya, Endonezya ve güney yarım kürenin diğer ekonomileri gün geçtikçe daha fazla yükselen yıldızlar olarak göze çarpmaktadır. Sinkovics vd. (2014)'ne göre bunun nedeni sadece kuzeydekilerle karşılaştırıldı ğında çok daha hızlı büyüyen ekonomileri değildir. Bu ülkeler, kuzeydeki gelişmiş ülkelere ders verecek nitelikte modellere sahip, yenilikçi küçük şirketlerin hayat bulduğu yerlerdir. $\mathrm{Bu}$ küçük, cesur, yenilikçi girişimler batılı büyük şirketlerin alanlarına da hiç korkmadan girebilmektedirler.

Geniş coğrafyası ve büyük nüfusuyla Hindistan, gelişmekte olan ülkeler arasında en dinamik ve aynı zamanda en sorunlu olanlardan biridir. Gelir dağılımı eşitsizliği sebebiyle aşırı fakirlik ve yüksek refah bir arada görülebilmektedir. Bununla birlikte, iklim ve coğrafi koşulların çetinliği sebebiyle, bu büyük nüfusun \% 70'inden fazlası şehirlerden uzakta, sayıları 550.000'i aşan köylerde yaşamaktadır (Mehta 2012, 177). Bu haliyle Hindistan, uzun zamandan beri sosyal yenileşim için tasarım alanında hem ulusal hem de uluslararası önemli aktörlerin sık sık boy gösterdiği sahnelerden biridir.

Hindistan'ın tabandan doğacak yerel girişimlere tasarım desteği konusundaki deneyimi ise kesinlikle bir rastlantı değildir. 1979'da Ulusal Tasarım Enstitüsü'nde (NID) gerçekleştirilen Ahmedabad Konferansı, ülkenin tasarım politikalarında, Schumacher ve Papanek'in savundukları toplum odaklı projelerinin dillendirildiği bir dönüm noktası olmuştur. Ülkenin hala büyük saygı duyulan efsanevi lideri Gandi'nin de işaret ettiği türden; kendi kendine yeten, tabandan yükselen, harmonik kalkınma modeline uygun şekilde tasarım, Hindistan'da geleneksel toplum değenlerini korumak ve yeni iş imkânları yaratmak için yaptığı müdahalelerle özellikle yerelde mevcut yeteneklerin değerlendirilmesine, toplumsal yaşamın kumaşına işlenmiş dayanışma kültürünün güçlenmesine odaklanmaktadır (Mehta, 2012). 
Mehta (2012), NID'nin eğitimde seri imalata odaklı ürün tasarımının ötesine geçip, özellikle zanaat alanında son elli yıldır önemli görevler üstlendiğini vurgulamaktadır. NID öğrencileri ve mezunları hem zanaatın dokümantasyonunda hem de zanaat ürünlerinin modern pazarda yer bulmasında çeşitli roller üstlenmektedirler.

Tüm bu sebepler Hindistan'ı tasarımın müdahil olduğu ve kırsalda geçim kaynaklarının yaratıldı ̆̆ aktörleri tanımlamak ve sosyal yenileşim için tasarımın rollerini gözlemlemek için uygun bir laboratuvar haline getirmektedir. Bu bağlamda, tasarım eğitimi almış kişilerin müdahil olduğu, sosyal fayda sağlayan projeler araştırılmış ve halen devam eden analiz sürecinin ilk çıktıları olarak Tablo 1'de özetlenen verilere ulaşılmıştır.

Tabloda ismi geçen organizasyonlar şunlardır;

BCDI: Bamboo Cane Design InstituteBambu ve Kamış Tasarım Enstitüsü. Otonom çalışan kamuya bağlı bir organizasyondur. Hindistan'da bambu yetişen coğrafyalarda bambu kullanımını ve zanaatını arttırmak üzere ücretsiz eğitimler, atölyeler yürütmektedir. Aynı zamanda geniş makine ve teçhizat parkuruyla yerelde bambu ile yapılan ürünlerin tasarlanmasını desteklemektedir.

IIM-A: Indian Institute of Management Ahmedabad - Hindistan Yönetim Enstitüsü Ahmedabad; işletme, pazarlama, yenileşim, yönetim ve organizasyon alanına özelleşmiş bir eğitim kurumudur.

NID: National Institution of Design Ulusal Tasarım Enstitüsü, tasarım alanında ülkenin önde gelen eğitim kurumlarından biridir.

NIF: National Innovation Foundation Ulusal Yenileşim Fonu, kamuya bağlı, otonom çalışan, yenileşim kuluçkalama projeleri geliştiren bir organizasyondur. UNDP: United Nations Development Programme - Birleşmiş Milletler Kalkınma Programı. Milletler arası, kalkınmayı desteklemek amacıyla kurulmuş, kar amacı gütmeyen bir organizasyondur.

Bill \& Melinda Gates Vakfi: Sosyal fayda içeren projeler gerçekleştiren, kar amacı gütmeyen, uluslararası bir organizasyondur.

BMVSS: Bhagwan Mahaveer Viklang Sahayata Samiti, Jaipur merkezli, engelli insanların hayatlarını iyileştirmeye odaklı, kar amacı gütmeyen bir organizasyondur.

Manav Saddhana: Ahmedabad / Hindistan'da kurulmuş, maddi gücü yetersiz ailelerin çalışmak zorunda kalan çocuklarına eğitim vermeyi amaçlayan, kar amacı gütmeyen organizasyondur. D-Rev: Design Revolution, ABD'de kurulmuş, günlük geliri dört dolar altında olan insanların kullanımı için ürün tasarlayan ve geliştiren kar amacı gütmeyen organizasyon.

Design Impact: ABD'de kurulmuş, sosyal fayda içerikli tasarım hizmetleri sunan kar amacı gütmeyen organizasyon.

Tablo 1'de de görülebileceği gibi incelenen yedi vakada tasarımcıların büründüğü beş farklı kimlik göze çarpmaktadır.

Bunlar;

1. Akademisyen: Bir yüksek öğrenim kurumuna bağlı olarak çalışan araştırmacı. 2. Öğrenci : Bir yüksek öğretim kurumunda tasarım eğitimi alan kişi.

3. Serbest tasarımcı: Bağımsız ve bireysel olarak tasarım hizmeti veren tasarımcı. 4. Kar amacı gütmeyen bir organizasyonun üyesi: Kamu kurumu, özel işletme ya da bir sivil toplum örgütünün üyesi olan tasarımci.

5. Kar amacı güden bir organizasyonun Sayı 18, $2014 \mid 45$ 


\begin{tabular}{|c|c|c|c|c|c|}
\hline & Proje hedefleri & $\begin{array}{l}\text { Başlıca } \\
\text { paydaşlar }\end{array}$ & $\begin{array}{l}\text { Tasarımcıların } \\
\text { kimlikleri }\end{array}$ & $\begin{array}{l}\text { Tasarımcıların } \\
\text { üstlendikleri başlıca } \\
\text { roller }\end{array}$ & Sosyal yenileşimler \\
\hline $\begin{array}{l}\text { Katlamara } \\
\text { Chalo } \\
\text { Bamboo } \\
\text { Projesi } \\
\text { (Agartala) }\end{array}$ & $\begin{array}{l}\text { Bambu ziraatını } \\
\text { arttırmak. } \\
\text { Sürdūrūlebilir bir } \\
\text { malzeme olarak } \\
\text { bambunun imalatta } \\
\text { kullanırnını artıırnak } \\
\text { Bambu zanaatını } \\
\text { geliştirmek, yaymak. }\end{array}$ & $\begin{array}{l}\text {-UNDP } \\
\text {-NID } \\
\text {-Hindistan } \\
\text { Devleti } \\
\text {-BCDI }\end{array}$ & $\begin{array}{l}\text {-Akademisyen } \\
\text {-Ögrenci } \\
\text {-Serbest } \\
\text { tasarımci }\end{array}$ & $\begin{array}{l}\text {-Araştırmacı } \\
\text {-Stratejist } \\
\text {-Kapasite geliştirici } \\
\text {-Sohret } \\
\text {-Eş-yaratıcı } \\
\text {-Kolaylaştıncı } \\
\text {-Eylemci } \\
\text {-Sosyal girisimci } \\
\text {-Secenek yaratıcı } \\
\text {-Iş modeli geliştirici }\end{array}$ & $\begin{array}{l}\text {-Bambunun sürdūrülebilir } \\
\text { kullanımını artırmak } \\
\text { - Iş kaynakları yaratmak } \\
\text {-Egitim kurumları ile } \\
\text { kapasite arttırmak } \\
\text {-Yerel karar ve hareket } \\
\text { grupları oluşmasını } \\
\text { sağlamak } \\
\text {-Ulusal ve uluslararası } \\
\text { bag̈lantılar sağlamak }\end{array}$ \\
\hline $\begin{array}{l}\text { Jawaja Kırsal } \\
\text { Üniversite } \\
\text { Deneyi } \\
\text { (Ajmer) }\end{array}$ & $\begin{array}{l}\text { Ajmer/Jawaja } \\
\text { kırsalında yüksek } \\
\text { eğitimin doğrudan } \\
\text { katkısı ile eğitimi ve } \\
\text { kalkınmayı } \\
\text { desteklemek. } \\
\text { Deriden yapıımış } \\
\text { zanaat ürünleri ûreten, } \\
\text { kendi kendine yeten } \\
\text { yerel topluluklar } \\
\text { oluģturmak }\end{array}$ & $\begin{array}{l}\text {-IIM-A } \\
\text {-NID } \\
\text {-Hindistan } \\
\text { Deviefi }\end{array}$ & $\begin{array}{l}\text {-Akademisyen } \\
\text {-Ögrenci } \\
\text {-Serbest } \\
\text { tasarımcı }\end{array}$ & $\begin{array}{l}\text {-Araştırmacı } \\
\text {-Stratejist } \\
\text {-Kapasite geliştírici } \\
\text {-Eફ-yaratıcı } \\
\text {-Eylemci } \\
\text {-Kolaylaştıncı } \\
\text {-Arabulucu } \\
\text {-Koordinatör } \\
\text { - Hikaye anlatıcı } \\
\text {-Kılavuz } \\
\text { - Secenek yaratıcı } \\
\text {-Ticareti destekleyen } \\
\text {-Iş modeli geliştirici }\end{array}$ & $\begin{array}{l}\text {-Eḡitim ile kapasite } \\
\text { arttırmak } \\
\text {-Derinin daha verimli ve } \\
\text { sürdūrülebilir kullanılmasını } \\
\text { saģlamak } \\
\text { - Iş kaynakları yaratrnak } \\
\text {-Yerel karar ve hareket } \\
\text { gurupları oluşınasını } \\
\text { sağlamak } \\
\text {-Ulusal ve uluslararası } \\
\text { bağlantılar sağlamak }\end{array}$ \\
\hline $\begin{array}{l}\text { Kutch } \\
\text { Kala Raksha } \\
\text { Projesi } \\
\text { (Bhuj) }\end{array}$ & $\begin{array}{l}\text { Kutch bōlgesindeki } \\
\text { geleneksel nakıß̧ } \\
\text { zanaatını korumak ve } \\
\text { sūrdürmek, } \\
\text { Zanaatkarlara tasarım } \\
\text { teorisi ve pratı̆gini } \\
\text { kazandırmak }\end{array}$ & $\begin{array}{l}\text {-Hindistan } \\
\text { Devleti } \\
\text {-Kala Raksha } \\
\text {-NID }\end{array}$ & $\begin{array}{l}\text {-Akademisyen } \\
\text {-Kar amaci } \\
\text { gũden } \\
\text { organizasyon } \\
\text { - Kar amaci } \\
\text { gūtmeyen } \\
\text { organizasyon } \\
\text {-Serbest } \\
\text { tasarımcı }\end{array}$ & $\begin{array}{l}\text {-Araştırmacı } \\
\text {-Stratejist } \\
\text {-Kapasite geliştirici } \\
\text {-Eş-yaratıcı } \\
\text {-Kolaylaştıncı } \\
\text {-Koordinatör } \\
\text {-Sosyal girişimci } \\
\text { - Sefenek yaratıcı } \\
\text {-Ticareti destekleyen } \\
\text {-iş modeli geliştirici }\end{array}$ & $\begin{array}{l}\text {-Somut olmayan kũitūr } \\
\text { mirasını korumak } \\
\text {-Eğitim ile kapasite } \\
\text { attırmak } \\
\text {-Iş kaynakları yaratmak } \\
\text {-Yerel karar ve hareket } \\
\text { guruplanı oluşmasını } \\
\text { sağlamak } \\
\text {-Ulusal ve uluslararası } \\
\text { bağlantılar sağlamak }\end{array}$ \\
\hline $\begin{array}{l}\text { Honeybee } \\
\text { Network } \\
\text { Pamuk Ayrıcı } \\
\text { Makine } \\
\text { Projesi } \\
\text { (Ahmedabad) }\end{array}$ & $\begin{array}{l}\text { Kırsalda geliştirilmiş } \\
\text { 'pamuk ayrışırma } \\
\text { makinesi' tasarımını } \\
\text { kuluçkalamak }\end{array}$ & $\begin{array}{l}\text {-llM-A } \\
\text {-HoneyBee } \\
\text { Network } \\
\text {-NIF } \\
\text {-NID }\end{array}$ & -Öğrenci & $\begin{array}{l}\text {-Eq-yaratıcı } \\
\text {-Secenek yaratıci } \\
\text {-Ticareti destekleyen }\end{array}$ & $\begin{array}{l}\text {-İ kaynakları yaratmak } \\
\text {-Ulusal ve uluslararası } \\
\text { bağlantılar sağlamak }\end{array}$ \\
\hline $\begin{array}{l}\text { Quicksand } \\
\text { sanitasyon } \\
\text { projesi } \\
\text { (Delhi- } \\
\text { Banglaore) }\end{array}$ & $\begin{array}{l}\text { Sanitasyon altyapısı } \\
\text { olmayan yerler için } \\
\text { çözüm üretmek }\end{array}$ & $\begin{array}{l}\text {-Bill\&Melinda } \\
\text { Gates Vakhı } \\
\text {-Quicksand } \\
\text {-Yerel } \\
\text { Yỏnetimler }\end{array}$ & $\begin{array}{l}\text { - Kar amacı } \\
\text { güden } \\
\text { organizasyon }\end{array}$ & $\begin{array}{l}\text {-Kolaylaştıncı } \\
\text {-Kılavuz } \\
\text {-Görselleştiren } \\
\text {-Arabulucu } \\
\text {-Koordinatör } \\
\text {-Müzakereci } \\
\text {-Is modeli geliştirici }\end{array}$ & $\begin{array}{l}\text {-Yaşam kalitesini arttırmak } \\
\text { - İ̧ kaynakları yaratrnak }\end{array}$ \\
\hline $\begin{array}{l}\text { Earn and } \\
\text { Learn Projesi } \\
\text { (Ahmedabad) }\end{array}$ & $\begin{array}{l}\text { Şohrin dış } \\
\text { mahallelerinde yaşayan } \\
\text { sokak çocuklanna } \\
\text { temel eğitim sağlamak }\end{array}$ & $\begin{array}{l}\text {-Manav } \\
\text { Saddhana } \\
\text {-Dosign Impact }\end{array}$ & $\begin{array}{l}\text {-Kar amaca } \\
\text { gūtmeyen } \\
\text { organizasyon }\end{array}$ & $\begin{array}{l}\text {-Seçenek yaratıcı } \\
\text { - Hikaye anlatıcı }\end{array}$ & $\begin{array}{l}\text {-Eg̈itim, kapasitesi } \\
\text { arttırmak } \\
\text {-İş kaynakları yaratrnak }\end{array}$ \\
\hline $\begin{array}{l}\text { Jaipur Foot } \\
\text { Protez Projesi } \\
\text { (Jaipur) }\end{array}$ & $\begin{array}{l}\text { Ampute hastalar için } \\
\text { protez uzurvlar } \\
\text { sağlamak }\end{array}$ & $\begin{array}{l}\text {-BMVSS } \\
\text {-D-Rev. }\end{array}$ & $\begin{array}{l}\text {-Kar amaci } \\
\text { gũtmeyen } \\
\text { organizasyon }\end{array}$ & -Kolaylaştırıcı & $\begin{array}{l}\text {-Yaşarn kalitesini arttırmak } \\
\text {-l\$ kaynakları yaratmak }\end{array}$ \\
\hline
\end{tabular}


Tablo: , üyesi: Ürün ya da hizmet karşılığında kar Hindistan özelinde sosyal elde eden bir işletmede çalışan tasarımcı. yenileşim içerikli projeler

Bu kimlikler tasarımcının motivasyonunu, projeden beklentilerini, proje paydaşları ile kurduğu ilişkiyi ve projeye adayacağı zamanı doğrudan etkileyebilmektedir. Tüm bu etmenlere bağlı olarak, tasarımcının önereceği çözüm skalasının sınırları da değişmektedir.

Akademisyenler, sahip oldukları görev tanımlarına uygun şekilde araştırmacı rolünü üstlenmektedir. Yapılan araştırmalar yazılı ve görsel ortamlara kaydedilerek projenin ilerleyen safhaların diğer aktörlerin rollerini gerçekleştirmelerini kolaylaştırmaktadır. Bazen, projenin hedefi sadece yazılı ve görsel doküman oluşturmak ve arşivlemek bile olabilmektedir. Akademisyenlerin göze çarpan bir diğer rolü ise strateji geliştirmeleridir. Akademisyenler, rol aldıkları projelerde meseleyi bir misyoner gibi sahiplenmekte ve konunun hem teorik hem de pratik alanda ilerleyişini desteklemektedir. Bunu hem eğitim kurumlarında konu ile ilgili akademik tartışmaları ve araştırmaları tetikleyerek, hem de özel sektör ve devlet kurumları arasında arabulucu, ikna edici olarak gerçekleştirmektedir. Bu haliyle akademisyenler, çoğu zaman projenin şampiyonu ve bazen şöhreti dahi olabilmektedir.

Öğrenciler ise sayıca akademisyenlerden fazla olsa da genellikle kendilerine eğitim kurumlarınca verilen dersler, ödevler/projeler sayesinde, deneyim kazanabilmek için konu ile tanışmaktadır. Kısıtlı bir zaman süresince, akademisyenlerle karşılaştırıldığında daha az yoğun adanmışlık göstermektedirler. Bu sebeple, tasarım öğrencisinin rolü kendisine tanımlanan sınırlar içerisinde teorik ve pratik bilgi ve çözümler üretmektir. Öğrencilerin en önemli rollerinden biri eştasarımcı olmaktır. Öğrenciler, çözümün kendisini ya da çözüme ulaştıracak ürün ve hizmetleri yerel halk ile birlikte tasarlamaktadır.

Sosyal tasarım yapan ve kar amacı gütmeyen organizasyonlar oldukça ilginç ve ekonomik anlamda dışa bağımlı bir alanda ilerlemektedir. Bunlardan Design Revolution (D-Rev) ve Design Impact, ABD'den iki organizasyondur. Bu türden tasarım organizasyonlarının mensubu olan tasarımcılar sosyal fayda sağlamak için hali hazırda yerelde sosyal yenileşim yapan bir başka organizasyona destek vermektedirler. İncelenen iki örnekte de organizasyonlar herhangi bir strateji geliştirmemiştir. Örneğin, D-Rev, Jaipur Foot'un mevcutta tasarladığı, ürettiği ve ihtiyacı olan yürüme engelli insanlara ücretsiz olarak verdiği mekanik eklemleri yeniden tasarlamıştır $\mathrm{Bu}$ yeniden tasarım ile iyileştirilmiş olan ürün, BMVSS'nin hizmet sürecini ve insanların yaşam kalitesini iyileştirmekte, sosyal faydanın ortaya çıkmasını kolaylaştırmaktadır.

Kar amacı güden organizasyonların üyesi olan tasarımcılar, Quicksand örneğinde olduğu gibi sosyal fayda amaçlayan projelerde tasarım hizmeti sağlamaktadırlar. $\mathrm{Bu}$ her ne kadar prensipte ticari bir faaliyet olarak dünyanın herhangi bir yerindeki tasarım danışmanlık şirketinin verdiği hizmete benzese de, aslında tasarımcılar özellikle kalkınma ajansları ve fonları ile yerel halk ve yerel yönetimler arasındaki ilişkiyi sağlamaktadır. İngiltere ve Amerika'daki örneklerine benzer olarak Hindistan'da da tasarımcılar eş-tasarımcı, görselleştirici, hikaye anlatıcı gibi insan odaklı tasarım yaklaşımının öngördüğü rollerin yanı sıra arabulucu, Sayı 18, $2014 \mid 47$ 
müzakereci gibi roller de üstlenmektedirler. Fakat batıdaki örneklerinin bir adım ötesinde, Hindistan örneğinde sosyal fayda sağlama amaçlı sanitasyon projesinde bu tasarım şirketi, proje tanımında olmasa da yereldeki koşulları daha iyi algılayabildiği için iş modeli geliştirici rolünü de üstlenmiştir.

Daha önce literatürde tanımlanmış rollerle birlikte, Hindistan'dan seçilmiş sosyal yenileşim içerikli projelerinde tasarımcılar; iş modeli geliştirici ve seçenek yaratıcı rollerini üstlenebilmektedir.

Seçenek yaratıcı görevi, tasarımcının tüketiciler için sosyal katma değeri piyasadaki muadillerine göre daha fazla ya da daha sürdürülebilir olan ürün ve hizmetler tasarlamaktır. Bambu örneğinde bu, yoksullukla savaşan bir köyde tasarlanmış ve el emeği ile üretilmiş, doğaya olumsuz etkisi az mobilyalar iken Kala Raksha örneğinde yine yerel kaynaklar ile üretilmiş, geleneksel anlamın ve somut olmayan kültür mirasının korunmasını sağlayan nakışlı tekstil ürünleridir. $\mathrm{Bu}$ değer katma süreci, tasarımın seri imalat ürünlerinde yarattığı katma değere benzer kurallarla fakat farklı bir perspektifte işlemektedir.

İş modeli geliştirme ise verilen örneklerde saptanmış en karmaşık rollerden biridir. Zira bu rol, tasarımcılık ile girişimcilik arasında ince bir çizgiyi tarif etmektedir. Tasarımcı bir girişimci gibi ticari iş modelinin tüm unsurlarını düşünmekte, ürün, üretim koşulları ve son kullanıcının beklentilerini tahlil etmekte ve tüm bunları uzun vadeli bir plan olarak ortaya koymaktadır. Bu planı kendi geçekleştirdiğinde girişimci, planın yereldeki paydaşlar tarafından gerçekleştirilmesini destekle- diğginde ise iş modeli geliştirici olmaktadır.

Tasarımcıların projelerde edindikleri kimlikler ve ortaya çıkan sosyal yenileşimler arasındaki ilişki ise şöyle özetlenebilir; -Akademisyenler daha uzun soluklu müdahil oldukları projelerde öğrencilere de rol vererek hem bilgi ve becerinin akademik müfredata uygun olarak aktarılmasını sağlamakta hem de yereldeki paydaşlar ile ülkenin farklı yerlerinden gelen bu genç tasarımcılar arasında bir bağ kurarak daha sonra devam edebilecek ortaklıklar için zemin hazırlamaktadır. NID bu projelerden ilk ikisinin ana aktörü (Katlamara Chalo ve Jawaja deneyi), diğer

ikisinin (Kutch-Kala Raksha, HoneyBee NetworkPamuk ayırıcı makine) ise önemli paydaşları arasında yer almaktadır. NID'nin bu aktif rolü enstitünün eğitim politikasına kazınmış felsefesinin bir yansıması olarak görülebilir. NID'nin hedeflediği ve uyguladığı tasarım müdahaleleri çoğu zaman zanaat odaklı çalışan küçük girişimlerde değişimin katalizörü olmakta, yeni vizyonların gelişmesi için destek vermektedir. Bu sayede de Hindistan'ın sürdürülebilir kalkınmasına katkıda bulunmaktadır (Mehta, 2012, 183). Tasarım eğitimi ve sosyal fayda arasındaki ilişkiyi daha iyi anlayabilmek için enstitünün eğitim politikaları, devletle ve diğer aktörlerle olan ilişkisi incelenmelidir.

-Akademisyenlerin, hem koordinatör hem de stratejist olduğu ilk iki vakada yerel malzemenin sürdürülebilir kullanımı, geçim kaynakları oluşturulması, kapasite arttırılması gibi daha bütüncül sosyal iyileşmelere yol açtıkları gözlemlenmektedir. Diğer yandan daha kısıtlı roller edindikleri projelerde ise yaşam kalitesini iyileştirmek, iş kaynakları geliştirme eğitim ile kapasite attırmak, yerel karar ve hareket grupları oluşmasını sağlamak, ulusal ve uluslararası bağlantılar sağlamak 
gibi sosyal faydaların ortaya çıkmasına destek vermektedir.

-Öğrenciler tanımlı süreler içinde katıldıkları projelerde her zaman beklenen adanmışlığg göstermeyebilmektedirler. Dolayısıyla bu sosyal yenileşimin ortaya çıkmasında riskli bir zemin oluşturabilmektedir.

-Bununla birlikte öğrencilerin bir kısmı, akademisyenler aracılığıyla tanıştığı bu yeni ekosistemde yeni beceriler edinmekte, yerel halk ve tasarıma konu olan malzeme ile derin bağlar oluşturabilmekte ve öğrenimini tamamladıktan sonra da serbest tasarımcı olarak bu türden projelerde yer alabilmekte, girişimlerde bulunabilmektedir.

-Tasarımcının kimliğinden ve proje tanımından bağımsız olarak, Hindistan'ın yoksulluk ve işsizlikle örülmüş kendi koşulları gereği iş kaynaklarını arttırmak tüm projelerin ortak çıktısı olabilmektedir. Örneğin kar amacı güden bir tasarım danışmanlık firması olan Quicksand, sanitasyon ve tuvalet hijyeni odaklı bir projede, diğer paydaşların böyle bir beklentisi olmasa da, yereldeki paydaşların yaşam biçimi üzerine yaptığg araştırmalar sonucu, onları kapsayacak bir iş modeli de geliştirerek çözüme ulaşmayı tercih etmiştir. Bu gelişmekte olan ülkelerde iktisadi değer ile sosyal değerin birlikte düşünülmesi gereğine bir örnektir.

-Kar amacı gütmeyen organizasyonlar, buldukları desteklerle kendi ekonomik varlıklarını sürdürürken, kendi seçimleri ile sosyal fayda amaçlayan projelerde yer alabilmektedirler. Burada projenin sınırlarını ve oluşacak sosyal faydayı belirleyen ana etmen yerelde projeyi başlatan ve yürüten organizasyondur. $\mathrm{Bu}$ organizasyon tasarımcı için tanımlı bir düzlem çizmekte ve belirlenen zamanda öngörülebilen çıktılar beklemektedir. Bu türden bir ilişki gönüllü tasarımcıların da sisteme müdahil olmasını kolaylaştırmaktadır. Tasarımcıların rolü, kar amacı güden örneklere nazaran daha sınırlandırılmış gözükse de proje süresince diğer paydaşları anlayabilmeleri, onlarla birlikte çalışabilmeleri ve özellikle de projeye konu olan yerel halkın sosyal meselelerini analiz edebilmeleri için tasarımın nosyonuna dahil olan çekirdek bilgi ve becerilerin ötesinde becerilere sahip olmak zorundadırlar. Bu durum da yine T tipli tasarımcı tanımına vurgu yapmaktadır. -Gönüllü veya serbest tasarımcılar, kar amacı gütmeyen ve sosyal fayda amaçlı tasarım hizmeti veren organizasyonlarda yer alarak daha esnek ve hızlı hareket edebilmekte, yereldeki insanların yaşam kalitesini yükseltmekte ya da tüketici için sosyal katma değeri yüksek seçenek yaratabilmektedir. Diğer taraftan kar amacı güden ve sosyal fayda amaçlı tasarım hizmetleri de veren organizasyonlar daha büyük fonlarla birlikte, daha uzun vadeli projelerde yer alabilmekte, bu projeleri yürütmek, devlet ve yerel yönetim ile proje paydaşları arasında arabuluculuk yapmak gibi roller üstlenebilmektedirler.

\section{Sonuç ve Tartışma}

Sosyal yenileşim, göreli olarak basit fakat dinamik bir süreçtir. Bu süreç yeni bir denge yaratmak, yeni bir fırsat keşfetmek, değişim için fikir geliştirmek, bu fikri harekete geçirmek, sonra da onun büyümesini ve yayılmasını sağlamak, momentini koruyup sürdürmek, ve nihayetinde sosyal değişimin seyrini yönlendirmek adımlarını içerecektir.

Çalışmanın amacı sosyal fayda içeren projelerde tasarım, sürdürülebilir kalkınma ve sosyal yenileşim arasındaki ilişkiyi kurmak ve tasarımcının değişen rollerini saptamaktır. Sosyal yenileşim içerikli projeler kalkınmış batılı ülkelerde, kalkınmakta 
olan ülkelerde ve piramidin tabanı olarak nitelendirilen üçüncü dünya ülkelerinde farklı yaklaşımlarla ve uygulamalarla gerçekleşmektedir. Bu sebeple tasarımcıların değişen kimliklerini ve rollerinin projenin gerçekleştirileceği yerel bağlama uygun olarak tanımlanmasına ihtiyaç vardır.

Çalışma kalkınmış ülkeler ile piramidin tabanı olarak nitelendirilen ülkelerden farklı olarak, ikisinin arasında, her ikisinin de sahip olduğu karakteristik özelliklere sahip olabilen ama bununla birlikte kendi sosyokültürel dinamiklerine bağlı olarak özgünleşen, Hindistan, Brezilya, Türkiye gibi ülkelere odaklanmıştır. Bu bağlamda çalışma, kalkınmakta olan ülke perspektifini kullanarak, literatürde yer alan ve tasarımcıların değişen rollerini keşfetmeye odaklı diğer yazınlardan farklılık göstermektedir.

Hindistan özelinde incelenen projeler, ülkenin bütünündeki sosyal fayda içerikli çalışmaları özetlemeye yetemeyecek kadar sınırlıdır. Aynı zamanda projelerin araştırılmasında proje başına ayrılan zaman, dil ve iletişim sıkıntıları ile birlikte tüm projelerin aynı derinlikte incelenmesini olanaksız kılmıştır. Bu sebeple de belirlenen örnekler arasında, kalkınma ve tasarım konusuna yaklaşımıyla diğer tasarım enstitülerinden ayrışan NID’nin yer aldığı projelere odaklanılmıştır. İncelenen projelerde görülmüştür ki sosyal fayda içerikli projelerde tasarım; zanaat odaklı veya tarım dışı faaliyet gösteren çok küçük işletmelerin kapasitelerini artırmakta, dezavantajlı topluluklar için ürün, hizmet, altyapı geliştirme faaliyetleri göstermektedir.

Tasarımcılar ise bu türden projelerde beş farklı kimlikle yer almaktadır. Bunlar; akademisyen, öğrenci, serbest tasarımcı, kar amacı gütmeyen bir organizasyonun üyesi ve kar amacı güden bir organizasyonun üyesi.

$\mathrm{Bu}$ kimlikler tasarımcının motivasyonunu, projeye ayıracağı zamanı ve adanmışlığını etkilemektedir. Sosyal fayda içerikli projelerde yerel paydaşlarla geçirilecek zamanın niteliği kadar niceliği de önemlidir. Bu sebeple proje alanında diğer kimliklere göre daha fazla vakit geçirebilen ve emek harcayabilen akademisyenler, projelerde strateji belirleyerek kilit rol üstlenmektedirler.

Hindistan özelinde, literatürün de varsaydığg gibi, sosyal fayda ve ekonomik fayda birlikte ortaya çıkmaktadır. Bu birliktelik organizasyonların yaklaşımlarına ve çözümlerine doğrudan yansımaktadır. Bu sebeple de tasarımcılar, her ne kimlikle olursa olsun, kalkınmakta olan bir ülkede sosyal yenileşim içerikli bir proje gerçekleştirirken ekonomik ve sosyal değeri birlikte üretebilmeye odaklanmalıdır. Diğer taraftan, kimlikler arasındaki geçiş, sektörler arasındaki geçişkenliğin bir yansıması olarak sıklıkla gözlemlenebilmektedir. Tasarımcının kimliğindeki bu geçişkenlik, özünde yöntemlerini çok etkilemese de projedeki rolünü değiştirmekte, getirdiği çözüm önerilerinin sınırlarını çizmektedir.

Tasarımın yerelde küçük, açık ve bağlı girişimlerin tetiklenmesi, geçim kaynaklarının oluşmasındaki bir diğer önemli rolü tüketici davranışını değiştirmek olacaktır. Bunu tüketici için daha sürdürülebilir seçenekler oluşturarak ve tüketici davranışını, sosyal değeri muadillerinden daha fazla olan ürün ya da hizmeti tercih etmesi yönünde motive ederek gerçekleştirebilecektir. Seçenek oluşturmada yeteneklerini iyi kullanan 
tasarımcı, belki de T tipi olmanın vereceği yeni yetilerle bu seçeneklerin tercih edilmesi için daha verimli yaklaşımlar geliştirmelidir. T tipi tasarımcı olgusu, bu farklı kimlikler ve rollerle birlikte, T'nin yana uzaman kollarını betimleyebilmek için detaylı olarak tartışılmalıdır. Bunun tasarım eğitimindeki yansımaları da başka bir araştırma konusu olabilir.

$\mathrm{Bu}$ araştırma sonucunda Hindistan örneğinin ülkemiz için de verimli sonuçlar vermeye müsait olduğu görülmektedir.

Fakat ülkemizde bu türden uygulamaları çoğaltmak ve sürdürebilmek için öncelikli olarak cevaplanması gereken iki soru vardir;

-Tasarım eğitimi bu türden kimliklere bürünecek ve bu türden roller üstlenecek tasarımcı adaylarını yetiştirmek için nasıl evrilmelidir?

-Hindistan'ın sosyal yenileşim için tasarım yaklaşımı, gelişmiş ülkelerden gelen tasarım şirketlerinin önerisinden özellikle geçim kaynakları yaratmaya ve zanaata olan vurgusuyla ayrışmaktadır. Ülkemizin yoksullukla mücadele ve kalkınma hedeflerine uygun olarak, sosyal problemlerin giderilmesine odaklanacak bir tasarım yaklaşımı geliştirilebilir mi?
Kaynakça

Amir, S. 2004. Rethinking Design Policy in the Third World. Design Issues. 20(4), s. 68-75

Auersweld, P. 2009. Creating Social Value. Stanford Social Innovation Review. 7(2), s. 51-55

Brown,T. 2009. On Being T-Shaped. [çevrimiçi]. Erişim yeri: http://www.core77.com/hack2work/ 2009/09/on_being_tshaped.asp [Erişim Tarihi: 01 Haziran 2014]

Brundtland, G. H. 1987. Our common future. New York: Oxford University Press

Buchanan, R. 2008. Introduction: Design And Organizational Change. Design Issues 24(1), s. 2-9

Ellis, F., \& Biggs, S. 2001. Evolving Themes In Rural Development 1950s?2000s. Development Policy Review 19(4), 437-448

Emilson, A., Seravalli, A., \& Hillgren, P. 2011. Dealing With Dilemmas: Participatory Approaches In Design For Social Innovation. Swedish Design Research Journal. (1), s. 23-29

Er, Ö., \& Kaya, Ç. 2008. Problems or Opportunities?: Overcoming the Mental Barrier for Socially Responsible Design in Turkey. The Design Journal. 11(2), s. 159-181

Güler B. K., 2011. Yoksullukla Mücadelede Sosyal Girişimcilik: Ashoka Üyelerinden Sosyal Yenilikçi Örnek Uygulamalar. Dokuz Eylül Üniversitesi Sosyal Bilimler Enstitüsü Dergisi. 13(3), s. 79-111

İnal M.E. ve Biçkes M. D. 2006. Kar Amaçsız Kuruluşların Sorunlarının Çözümünde Pazar Yönlülük Teorisi. Erciyes Üniversitesi Íktisadi ve İdari Bilimler Fakültesi Dergisi. 26, s. 45-65

Jégou, F. ve Manzini, E. 2008. Collaborative Organisations And Enabling Solutions Social Innovation And Design For Sustainability. Collaborative ser vices: Social innovation and design for sustain ability. ed. Jégou, F. ve Manzini, E. Milan, Italy: Edizioni POLI.design. s. 29-41

Jonas, W., Morelli, N., ve Münch, J. 2009. Designing a product service system in a social framework: methodological and ethical considerations. Undisciplined! Proceedings of the Design Research Society Conference 2008. ed. Durling, D., Rust, C., Chen, L-L., Ashton, P. ve Friedman, K. Sheffield: Sheffield Hallam University, s. 104 1-24, Erişim yeri: http://shura.shu.ac.uk/drs2008/ [Erişim tarihi: 01 Haziran 2014]

Manzini, E. 2012. Emerging Scenariol Small, Open, Local, Connected. Inovação Social E Sustentabilidade: Desenvolvimento Local, Empreendedorismo E Design Rio da Janeiro. ed. Bartholo, R., ve Cipolla, C. E-Papers Serviços Editoriais Ltda. s. 15-34

McCullagh, K. 2010. It's time to rethink the T-shape design ers? [çevrimiçi]. Erişim yeri: http://www.core77.com/ blog/columns/is_it_time_to_rethink_the_tshaped_designer_17426.asp [Erişim tarihi: 02 Haziran 2014]

Mehta, S. 2012 Design To Connect I Encouraging Social 
Innovations And Sustainability In The Indian Context. .Inovação Social E Sustentabilidade: Desenvolvimento Local, Empreendedorismo E Design Rio da Janeiro. ed. Bartholo, R., ve Cipolla, C. E-Papers Serviços Editoriais Ltda. s. 177-193

Meroni, A. 2012. Designing for social innovation I The pro ject "Feeding Milano. Energy for Change". Inovação Social E Sustentabilidade: Desenvolvimento Local, Empreendedorismo E Design Rio da Janeiro. ed. Bartholo, R., ve Cipolla, C. E-Papers Serviços Editoriais Ltda. s. s. $155-174$

Morelli, N. 2007. Social Innovation and New Industrial Contexts: Can Designers" Industrialize" Socially Responsible Solutions?. Design Issues. 23(4). s. 3-21

Murray, R., Caulier-Grice, J., ve Mulgan, G. 2010. The Open Book of Social Innovation. London: The Young Foundation

Phills, J. A., Deiglmeier, K., \& Miller, D. T. (2008). Rediscovering social innovation. Stanford Social Innovation Review 6(4), s. 34-43.

Redclift, M. 2005. Sustainable Development (1987-2005): An Oxymoron Comes Of Age. Sustainable Development. 13(4), s. 212-227

Romero S. Broder M. 2012. Progress on the Sidelines as Rio Conference Ends. [çevrimiçi]. Erișim Yeri:http://www.nytimes.com/2012/06 /24/world/americas/rio20-conference- endswith-some-progress-on-the-sidelines.html [Erisim tarihi: 01 Haziran 2014]

Sinkovics, N., Sinkovics, R. R., ve Yamin, M. 2014. The Role Of Social Value Creation In Business Model Formulation At The Bottom Of The Pyramid-Implications For MNEs. International Business Review. 23 (4), s. 692-707

T.C. Başbakanlık Devlet Planlama Teşkilaatı Müsteşarlığı 2010. Binyıl Kalkınma Hedefleri Raporu 2010, Ankara. [çevrimiçi]. Erişim yeri:http://www.tr.undp.org/content/dam /turkey/docs/Publications/mdgs/UNDP-TRTR\%202010\%20MDG\%20Report_TR.pdf [Erişim tarihi: 10 Mayıs 2014]

T.C. Kalkınma Bakanlığ 1 , 2014. Sürdürülebilir Kalkınma Protal - Yeşil Büyüme. [çevrimiçi] Erişim yeri:http://www.surdurulebilirkalkinma.gov.tr/ Rio+20.portal [Erişim tarihi: 01 Haziran 2014]

T.D.K. 2014. Bilim ve Sanat Terimleri Ana Sözlüğüu. Kalkınma. [çevrimiçi] Erişim yeri: http://www.tdk.gov.tr/index.php?option=com_ bilimsanat\&view=bilimsanat [Erişim tarihi: 01 Haziran 2014]

Tan, L. (2012). Understanding The Different Roles Of The Designer In Design For Social Good: A Study Of Design Methodology In The DOTT 07 (Designs Of The Time 2007) Projects. Doktora Tezi, Northumbria University

Valtonen, A. 2005. Six decades - and six different roles for the industrial designer. Nordes Conference In the Making. Copenhagen, 30-31 May, 2005 [çevrimiçi] Erişim yeri:http://www.nordes.org/ opj/index.php/n13/article/view/233/216 [Erişim tarihi: 01 Haziran 2014]
Yavuz, H. 2007. İnovasyon İçin T Tipi Çalışana İhtiyacınız Var. [çevrimiçi]. Erişim yeri: http://www.capi tal.com.tr/“inovasyon-icin-t-tipi-calisana-ihtiy aciniz-var"-haberler/19361.aspx [Erişim tarihi: 01 Haziran 2014] 